TOWARDS OPERATIONAL DISEQUILIBRIUM MACRO ECONOMICS 


\section{Towards Operational Disequilibrium Macro Economics}

JAN C. SIEBRAND

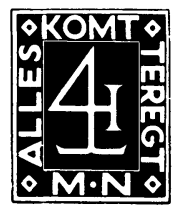

Springer-Science+Business Media, B.V. 1979 
ISBN 978-90-247-2153-5 ISBN 978-94-017-3561-2 (eBook)

DOI 10.1007/978-94-017-3561-2

(C) 1979 by Springer Science+Business Media Dordrecht.

Originally published by Martinus Nijhoff Publishers bv, The Hague in 1979.

Softcover reprint of the hardcover 1st edition 1979

All rights reserved. No part of this publication may be reproduced, stored in a retrieval system, or transmitted in any form or by any means, mechanical, photocopying, recording, or otherwise, without the prior written permission of the publisher, Springer-Science+Business Media, B.V. 


\section{Contents}

Preface $\quad$ ix

$\underline{\text { List of symbols }} \quad$ xi

1. Introduction 1

2. Quantity and price determination in disequilibrium 16

2.1. Introduction 16

2.2. Causes of disequilibria 16

2.3. Signs of disequilibrium 18

2.4. The modeling of disequilibrium economics in general 20

2.5. Some recent studies on the dynamics of price and quantity adjustment 21

2.6. The relevance of recent developments in disequilibrium theory for empirical macro economics 25

2.6.1. The limitations of available disequilibrium theory 25

2.6.2. The core of recent contributions 26

2.6.3. The adaptation of disequilibrium theory to empirical macro economics 27

2.7. Quantity and price determination in the case of 'compromising' 31

2.7.1. Some simple models of quantity and price formation 31

2.7.2. Complications 45

2.7.2.1. The impact of past frustrations 46

2.7.2.2. Disequilibria in different markets 47

$\begin{array}{ll}\text { 2.7.2.3. Ex ante adjustment } & 48\end{array}$

3. Statistical approximation to ex ante variables $\quad 52$

3.1. Introduction 52 3.2. The principles of the approximation to ex ante demand and
ex ante supply on the basis of data on actual transactions 
3.2.1. Principles 53

3.2.2. Application problems $\quad 55$

3.3. Concluding remarks 58

4. The application of the linear disequilibrium model to international trade 61

4.1. Introduction 61

4.2. The model 62

4.3. Application of the model 64

4.4. Evaluation 65

Appendix to Chapter 4: A comment on the application of the iterative method

5. The application of the non-linear disequilibrium model to the labour . market

5.1. Introduction 73

5.2. The model 74

5.3. Application of the model 83

$\begin{array}{ll}\text { 5.4. Evaluation } & 87\end{array}$

5.5. Some additional empirical studies 88

5.5.1. An approximation to potential supply in the product market 88

5.5.2. An approximation to ex ante credit demand, ex ante credit supply, ex ante investment and ex ante consumption 91

5.5.3. Further empirical ex ante/ex post research 91

Appendix to Chapter 5: An alternative estimation method 93

6. Simultaneous disequilibrium models for different markets 95

6.1. Introduction 95

6.2. The basic model in ex post terms 96

6.3. An ex post model based on ex ante terms 99

6.4. The determination of the ex ante terms 103

6.4.1. Introduction 103

6.4.2. The determination of planned variables 103

6.4.2.1. Expectation-approaches applied to plans 103

6.4.2.2. The determination of plans by means of behavioural
functions

6.4.3. The determination of the terms from behavioural
functions

6.4.3.1. The determination of expectations in the narrow
sense 
6.4.3.2. The determination of plans about other variables

6.5. The prospects for quantification of simultaneous ex ante/ ex post models

6.6. Complications

6.6.1. Decisions partly based on ex post information

6.6.2. Adjustment to prospects for the realization of plans within the model period

6.6.3. Direct impact from lagged tension between demand and supply

7. Examples of dynamic models in which adjustment is conditioned

by volume constraints

$\begin{array}{ll}\text { 7.1. Introduction } & 125\end{array}$

7.2. Hicks' model of the trade cycle 126

$\begin{array}{ll}\text { 7.3. A model with capital and labour constraints on output } & 127\end{array}$

$\begin{array}{ll}\text { 7.3.1. The model } & 127\end{array}$

7.3.2. Simulations 132

7.4. Prospects for empirical implementation of macro-economic multi-market disequilibrium systems $\quad 143$

Appendix to Chapter 7: Additional information on Model 7.2. 146

A. Graphic illustration of the investment function 146

B. Comment on the input of the reference version 148

C. Solution of the reference version for 65 periods 149

$\begin{array}{ll}\text { D. Survey of simulations } & 150\end{array}$

8. Summary and conclusions 153

$\begin{array}{ll}\text { References } & 158\end{array}$

$\begin{array}{ll}\text { Author index } & 163\end{array}$

$\begin{array}{ll}\text { Subject index } & 165\end{array}$ 


\section{Preface}

Most recent contributions to disequilibrium theory have a high level of abstraction. Empirical studies explicitly based on disequilibrium are still relatively scarce. However, empirical macro economics anticipated the theoretical development, and amalgamated classical and Keynesian elements often without a clear-cut formal base. Now a theoretical integration of neo-classical and neo-Keynesian economics seems under way. There is a renewed interest in the micro-economic foundations of macro economics with a special focus on the behaviour of economic agents operating in non-clearing markets. In some instances these theoretical developments offer an ex post justification for empirical macro-economic practices. Generally however, they call for new ways of empirical macro-economic model building.

This study operates on the border line between empirical macro economics and theoretical disequilibrium macro-economic theory. Our interest in macro-economic disequilibrium originates from the empirical side. Foreign trade relations for several countries revealed significant pressure of demand effects. Hence, the spillover of excess demand in domestic markets to foreign markets seemed a rather general phenomenon. This fact could be explained by a theory that states that actual demand for products from domestic firms will generally and systematically differ from the ex ante demand as suggested by equilibrium analysis. This latter demand concept comes close to Clower's 'notional demand' and Patinkin's 'potential demand'. Our first step in disequilibrium analysis was the construction of a model which determines this potential demand for domestic products as a function of potential imports and potential exports; the next was the development of an iterative estimation scheme for the empirical approximation of potential demand and its application to Dutch figures.

The idea that actual transactions could be conceived of as determined partly by neo-classical explanation schemes (based on items like prices) and partly by distribution devices such as rationing (often denoted as pressure effects) seemed general enough to try applications to other markets. The labour market held out a particular promise in this context. The analysis of wage-formation is generally based on disequilibrium schemes. Pressure effects are widely accepted in the analysis of short-term labour supply and furthermore there were signs that, for some periods in the sixties, actual employment in the Netherlands was suppressed 
by labour scarcity.

Our effort to identify potential demand and potential supply in the Dutch labour market called for the development of a more general disequilibrium model, however, and a more general iterative approximation method. The model developed contains the conventional minimum model based on the so called principle of 'voluntary trade', i.e. with rigid prices actual transactions are equal to the minimum of demand and supply, as a special case. We argue that, as a rule, transactions are a compromise between the wishes of demanders and those of suppliers, more or less tending to the minimum. Technically this means that transactions are a weighted average of potential demand and potential supply, the weights of supply tending to zero in case of abundant excess supply (the Keynesian view of the thirties, applied to other economic conditions long after date) and transactions close to potential supply in periods of great excess demand (perhaps in a major part of the after war years, in which supply-oriented growth models became popular).

The application of ex ante/ex post analysis to partial models of product demand, and of demand and supply in the labour market, raises the question of their mutual integration. Our analysis of this question suggests that interpretable multi-market ex ante/ex post macro-economic models may be derived from rather conventional ex post models, under some simplifying assumptions. Theoretical feasibility of such ex ante/ex post models does not imply however that their implementation will be an easy task. In fact, the approximation to ex ante variables is generally a relatively complicated matter. Nevertheless, it seems worthwhile, as these models can contribute to the understanding of the behaviour of economic agents under the joint impact of equilibrium considerations and disequilibrium constraints. The further integration of short-term models and growth models, in particular, may benefit from ex ante/ex post analysis. To demonstrate this, we linked up with Hicks' theory of constrained cycles and built a two-market recursive dynamic model. In this model not only the labour-supply constraint, but also the availability of material production capacity - as a backbone of potential supply - together with potential demand for products and potential demand for labour, determine the transactions in both markets: production and employment.

In our view, the full scale empirical implementation of disequilibrium principles to macro-economic model building is not a matter of a few man-years; therefore, this book just gives some basic tools for a new approach with a few examples of their use. A large part of the hard work still remains to be done. We hope to have shown that the prospects for a gradual integration of the 'new macro economics' in macro-econometric model building are promising. 


\section{List of symbols}

General

1) Lower-case letters stand for quantities in terms of constant prices or price variables.

2) Greek letters indicate coefficients.

3) Letters without a small o denote levels of variables.

4) Letters with a small o denote (annual) percentage changes of variables $\left(\stackrel{0}{x}=100 . \frac{x_{t}-x_{t-1}}{x_{t-1}}\right)$.

5) The use of the symbol $\Delta$ preceding a variable indicates a first difference operation applied to that variable $\Delta \mathrm{x}_{\mathrm{t}}=\mathrm{x}_{\mathrm{t}}-\mathrm{x}_{\mathrm{t}-1}$.

6) Letters with a bar $(-)$ denote average values; $\overline{\mathrm{O}}$ denotes the average value of $\mathrm{X}, \overline{\mathrm{x}}$ denotes the average value of $\mathrm{x}$.

7) Variables for the current year do not have a numerical suffix. They may or may not have the suffix $t$.

A lag of $1,2, \ldots \ldots, n$ periods is indicated by either $-1,-2, \ldots,-n$ or $\mathrm{t}-1, \mathrm{t}-2, \ldots, \mathrm{t}-\mathrm{n}$.

A lead of $1,2, \ldots, n$ periods is indicated by either $1,2, \ldots, n$ or $t+1, t+2$, ....., $\mathrm{t}+\mathrm{n}$.

The suffix $t 4321$ denotes a specific lag structure:

$\mathrm{x}_{\mathrm{t} 4321}=0.4 \mathrm{x}_{\mathrm{t}}+0.3 \mathrm{x}_{\mathrm{t}-1}+0.2 \mathrm{x}_{\mathrm{t}-2}+0.1 \mathrm{x}_{\mathrm{t}-3}$.

The suffix 0 refers to a base year, the suffix 60 to 1960 etc.

8) The suffix au denotes an autonomous component of the variable under consideration.

The suffixes $d$ and $s$ are used to indicate ex ante demand and ex ante supply 
variables respectively, or, in the case of prices, anticipations of potential buyers and potential sellers respectively.

The suffixes de and se refer to effective demand and effective supply respectively.

The corresponding variables without a suffix indicate the (ex post) realizations. Where needed, ex ante variables are also labeled with an upper index p ('potential') to differentiate between ex ante variables without a clear-cut demand or supply nature and ex post variables. In Chapter 6 this upper index is combined with a second letter b ('business'), $\mathrm{p}$ ('private households') or w ('world'), to indicate anticipations of different agents.

9) As a consequence of their hypothetical character, the definitions of ex ante variables in this list are only rough, as the accurate meaning of these variables can only be defined in the context (model) in which they are used.

10) Labour-market variables referring to numbers of persons are denoted with the basic symbol 'a', variables based on 'constant-working-hours-man-years' with the basic symbol ' $l$ '. These variables can coincide if no changes in working hours are assumed.

\section{Specific}

$a_{a}$ dependent labour force

ab employment in industry

$a_{d}$ potential labour demand in industry

$\mathrm{ab}_{\mathrm{se}}$ effective labour supply for industry

$a_{c}$ total actual labour demand (industry and government)

ad potential total labour demand (industry and government)

ag government employment

$\triangle \mathrm{a}_{\mathrm{m}}$ net foreign migration of (potential) workers

an capacity employment, including the impact of normal contractual working hours

ap number of frontier workers

as total potential labour supply (industry and government)

ase total effective labour supply (industry and government)

ay dependent labour force corrected for frontier workers

$a_{y_{s}}$ dependent potential labour supply corrected for frontier workers

$\mathrm{a}_{\mathrm{Z}}$ self-employed labour force

b exports of goods and services

$b_{d} \quad$ export demand (goods and services)

$b_{\mathrm{g}} \quad$ exports of goods

$b_{\mathrm{gd}}$ potential exports of goods

c consumption 
$c_{a}$ part of consumption planned ex ante

cap production capacity

$\mathrm{cb}$ basic consumption

$\mathrm{c}_{\mathrm{d}}$ consumption demand

$c_{r}$ part of consumption fixed ex post

$d_{i}$ determinant $i$ of potential demand

F labour share in total income of industry

g working-age population

$\mathrm{g}_{\mathrm{X}}$ working-age population corrected for external migrants

$h_{c} \quad$ index number of contractual working hours per man per year

i investment

$i^{*} \quad$ auxiliary variable investment determination

$\mathrm{i}_{\mathrm{a}}$ investment demand as determined by a curvilinear accelerator function

$i_{d}$ investment demand

il investment demand as determined by a linear accelerator function

in net investment

k capital stock

$l$ employment (quantity of labour expressed in man-years based on a constant number of working hours per man per year)

$\mathrm{L}$ wage income

$l_{\mathrm{b}}$ potential labour demand, including liquidity effect

$l_{\mathrm{d}} \quad$ labour demand

$\Delta_{\mathrm{e}} \quad$ change in capacity employment due to economic obsolescence

$l_{n} \quad$ capacity employment (at normal utilization rate)

$\mathrm{l}_{\mathrm{q}}$ liquidity ratio of industry

$l_{\mathrm{S}} \quad$ labour supply

$l_{\text {se }}$ effective labour supply

$\mathrm{m}$ imports of goods and services

$\mathrm{m}_{\mathrm{d}}$ import demand (goods and services)

$\mathrm{m}^{*} \quad$ age of the oldest vintage of capital goods

$\mathrm{m}_{\mathrm{g}}$ imports of goods

$\mathrm{m}_{\mathrm{gd}}$ potential imports of goods

$\mathrm{m}_{\mathrm{W}}$ world imports (weighted according to export shares)

$\mathrm{n}_{\mathrm{ba}}$ net inventory formation expressed as a percentage of sales, in deviation of the average value of this percentage

$\mathrm{n}_{\mathrm{i}}$ total number of social groups, relevant for labour supply

$\mathrm{n}_{\mathrm{D}}$ number of demand determinants

$\mathrm{n}_{\mathrm{S}}$ number of supply determinants

ob overtime index

$\mathrm{p}$ price

$\mathrm{P}$ prediction

$\mathrm{pb}$ export price

$\mathrm{p}_{\mathrm{b}}^{\prime} \quad$ price of competing exports

$\mathrm{p}_{\mathrm{c}}$ consumption price

pd price anticipated by potential buyers 
$\mathrm{pl} \quad$ wage rate (per man-year)

$\mathrm{plb}$ wage rate per worker

$\mathrm{p}_{\mathrm{m}}$ import price

$\mathrm{p}_{\mathrm{s}}$ price anticipated by potential sellers

$\mathrm{p}_{\mathrm{v}}$ price of sales

py price industrial production

$\mathrm{q}$ relative excess production capacity

$\mathrm{q}_{\mathrm{a}}$ relative excess production capacity, measured in deviation from its average value

r participation rate

$\mathbf{R}$ realization

$r^{*}$ domestic participation rate apart from demographic factors

$r_{i} \quad$ participation rate of social group $i$

$\mathrm{rS}_{\mathrm{S}}^{*} \quad$ upper limit of participation rate (saturation level)

s scrapping

Sj determinant $j$ of potential supply

$\mathrm{t}(\mathrm{T})$ time

$\mathrm{u}$ weight generally used to indicate the relative importance of the anticipations of potential sellers; the specific meaning of individual u's is explained by the context

$v$ sales

$v_{n} \quad$ domestic sales plus net exports of services

$\mathbf{v}_{\mathbf{n}_{\mathrm{d}}}$ potential domestic sales plus net exports of services

w unemployment rate

wp potential unemployment rate

$\mathrm{x}$ transactions

$\mathrm{x}_{\mathrm{d}}$ potential demand

$x_{d e}$ effective demand

$\mathbf{x}_{\mathbf{S}}$ potential supply

$\mathrm{x}_{\mathrm{Se}}$ effective supply

y industrial production

$\mathrm{Y}$ value industrial production (income)

yd potential demand for products

yed excess demand for products as a percentage of actual industrial production

$y_{i}$ component $i$ of $y$

$y_{i_{d}}$ component $i$ of $y_{d}$

$\mathrm{y}_{\mathrm{s}}$ component $\mathrm{i}$ of $\mathrm{y}_{\mathrm{s}}$

Yla agricultural production in deviation from its trend

$\mathrm{y}_{\mathrm{n}}$ net production

$\mathrm{y}_{\mathrm{n}}$ net demand for products

$\mathrm{y}_{\mathrm{n}}$ sk net material production capacity

$\mathrm{y}_{\mathrm{n}_{s} l}$ net product supply as conditioned by labour availability

$y_{p}$ real family income

ys potential supply of products 
$y_{\text {sc }}$ intended short-time supply of products (exclusive of the impact of the availability of labour and liquidities)

Ysh production at normal operating rates given contractual working hours of labour

ysk potential supply of products based on capital availability

$y_{s l}$ intended short-term supply of products including the impact of the availability of labour and liquidities

$z$ real nonwage income

$\mathrm{Z}$ nonwage income

$z / y$ real share of nonwage income

SD standard error of the regression

$\mathrm{R}^{2}$ coefficient of determination

DW Durbin-Watson ratio 